\title{
ANALISIS ANGIN ATAS DI WILAYAH JAWA BAGIAN BARAT SELAMA KEGIATAN TMC REDISTRIBUSI CURAH HUJAN
}

\author{
Erwin Mulyana *
}

\begin{abstract}
The Application of weather modification has carried out to redistribute precipitation over Jakarta and the surrounding on 26 January to 27 February 2013. Data used in this study are 3 hourly MERRA wind data $\left(1.25^{\circ} \times 1.25^{\circ}\right)$, daily NCEP wind data $\left(2.5^{\circ} \times 2.5^{\circ}\right)$, and gradient wind analysis data from BOM Australia. The westerly wind dominated over western part of Java. The wind direction in the western part of Java is strongly influenced by the tropical disturbance in the Indian Ocean south of Indonesia. The Tropical Cyclone Gino over Southwest Sumatera caused easterly wind over west part of Jawa. The wind speed up to 20 $\mathrm{m} / \mathrm{s}$ due to the effect of Tropical Cyclone Rusty in the west of Australia.
\end{abstract}

\section{Intisari}

Telah dilakukan analisis angin pada berbagai level ketinggian pada saat penerapan TMC yang dilakukan pada tanggal 26 Januari s.d 27 Februari 2013. Data yang digunakan adalah data angin tiga jam-an MERRA $\left(1.25^{\circ} \times 1.25^{\circ}\right)$, data angin harian NCEP $\left(2.5^{\circ} \times 2.5^{\circ}\right)$ serta angin gradient dari BOM Australia. Selama kegiatan, angin baratan mendominasi wilayah Jawa bagian barat. Arah angin di Jawa bagian barat sangat dipengaruhi oleh gangguan tropis yang muncul di Samudera Hindia sebelah selatan Indonesia. Terjadi pembalikan arah angin dari angin baratan menjadi angin timuran akibat pengaruh Siklon Tropis Gino di sebelah barat daya Sumatera. Kecepatan angin pada akhir kegiatan mencapai $20 \mathrm{~m} / \mathrm{s}$ akibat pengaruh Siklon Tropis Rusty di sebelah barat Australia.

Kata Kunci : Jawa bagian barat, angin atas, angin baratan, Siklon Tropis Gino, Siklon Tropis Rusty.

\section{PENDAHULUAN}

Iklim di Indonesia sangat dipengaruhi oleh system monsoon Asian-Australia (Ramage, 1986). Aldrian dan Susanto (2003) mengelompokkan pola hujan di Pulau Jawa kedalam pola monsoon yang dicirikan oleh bentuk pola hujan yang memiliki satu puncak musim hujan. Selama tiga bulan curah hujan relatif tinggi yang dikenal dengan musim hujan, yakni Desember, Januari dan Februari (DJF) dan tiga bulan curah hujan rendah disebut musim kemarau pada periode Juni, Juli dan Agustus (JJA). Sedangkan enam bulan sisanya merupakan periode peralihan yaitu tiga bulan peralihan kemarau ke hujan (SON), dan tiga bulan peralihan hujan ke kemarau (MAM). Namun demikian sering terjadi penyimpangan iklim

* UPT Hujan Buatan, BPPT yang berhubungan dengan ENSO (EI Nino Southern Oscillation) dengan perulangan antara 4 hingga 7 tahun. ENSO berpengaruh terhadap kekeringan akibat musim kemarau yang lebih lama dari biasanya (Ropelewski dan Halpert, 1989; Kane, 1997, Hamada, 1995; Aldrian, 2002; Mulyana, 2002). Perubahan temperatur permukaan laut di Samudera Hindia yang dikenal dengan Dipole Mode (IOD) juga berpengaruh terhadap curah hujan di Pulau Jawa (Saji et.al., 1999; Mulyana, 2002). Faktor lain yang mempengaruhi iklim di Jawa adalah Osilasi Maden Julian (Seto. T.H., 2002). Periode Maden Julian (MJO) berkisar antara 40 hingga 50 harian, sehingga berpengaruh terhadap variasi curah hujan dalam satu musim. Perubahan suhu muka laut di perairan sekitar Pulau Jawa juga berpengaruh terhadap cuaca dan iklim di Pulau Jawa. 
Setiap musim hujan, wilayah Jakarta dan sekitarnya selalu mengalami banjir baik dalam sekala besar maupun sekala kecil. Pada tanggal 17-18 januari 2013 banjir besar melanda Jakarta dan sekitarnya yang mengakibatkan korban jiwa dan kerugian ekonomi yang sangat besar. Untuk menghindari banjir susulan yang mungkin terjadi telah dilakukan upaya penerapan teknologi modifikasi cuaca (TMC) untuk redistribusi curah hujan di wilayah Jakarta dan sekitarnya.

Dalam tulisan ini akan dibahas kondisi angin atas di Jawa bagia barat selama kegiatan redistribusi hujan dengan TMC yang dilaksanakan di wilayah Jakarta dan sekitarnya pada tanggal 26 Januari sampai dengan 27 Februari 2013.

\section{DATA}

Data yang digunakan dalam tulisan ini adalah data angin di berbagai lapisan ketinggian yang berasal dari MERRA dan NCEP. Data MERRA merupakan data reanalisis angin dengan resolusi horizontal 1.25 derajat dengan 24 level ketinggian. Sedangkan data NCEP memiliki resolusi horizontal 2.5 derajat dengan variasi ketinggian sebanyak 17 level. Untuk menganalisis dan memvisualisasikan perubahan angin pada beberapa level ketinggian pada saat dilakukan kegiatan TMC redistribusi hujan dengan TMC di wilayah Jakarta dan sekitarnya digunakan software GrADS dan GIOVANNI. Sebagai data pelengkap digunakan data angin gradient dari Bureau of Meteorology (BOM) Australia.

\section{HASIL DAN DISKUSI}

Secara klimatologis, pengaruh monsun Asia terhadap wilayah Indonesia pada bulan Februari, mulai melemah (Aldrian, 2000). Daerah konvergensi massa udara umumnya terjadi mulai dari Lampung sampai Nusa Tenggara. Di daerah sebelah utara Australia terjadi daerah pusaran angin yang menunjukkan daerah yang sering terjadi siklon tropis. Walaupun monsun Asia mulai melemah, namun curah hujan di wilayah Indonesiai bagian selatan masih tinggi. Hal ini lebih cenderung karena daerah pertemuan masa udara dari belahan bumi utara dan selatan yang membentuk zona konvergensi intertropis (ITCZ) serta keberadaan siklon tropis di sebelah utara dan barat Australia. Daerah Lampung hingga Jawa pengaruh ITCZ lebih besar dibandingkan pengaruh siklon tropis, sedangkan daerah Nusa
Tenggara lebih dominan dipengaruhi siklon tropis yang terjadi di utara dan barat laut Australia. Pada bulan Januari dan Februari 2013 juga masih terjadi pola pusaran angin di sebelah barat hingga selatan Sumatera.

Adanya konvergensi dan pengaruh siklon tropis di selatan Jawa berpengaruh terhadap intensitas hujan serta arah dan kecepatan angin di Jawa. Siklon tropis di selatan Jawa pada umumnya mulai muncul pada bulan Desember dan terus berlanjut hingga bulan April tahun berikutnya. Berdasarkan Biro Meteorologi Australia (BOM), rata-rata jumlah siklon tropis yang muncul di selatan Jawa pada bulan Januari sebanyak 10 buah, sedangkan pada bulan Februari sebanyak 9 buah.

Berikut ini akan dibahas perilaku angin atas selama kegiatan TMC yang dilaksanakan dari tanggal 26 Januari sampai dengan 27 Februari 2013 di wilayah Jakarta dan sekitarnya. Level ketinggian angin mulai dari $925 \mathrm{mb}$ sampai dengan $300 \mathrm{mb}$. Perubahan arah dan kecepatan angin harian sangat dipengaruhi oleh adanya gangguan tropis berupa pusat tekanan rendah sampai siklon tropis yang muncul di Samudera Hindia selatan Indonesia.

\subsection{Angin $850 \mathrm{mb}$ vs waktu}

Seperti telah disinggung sebelumnya, angin di Jawa pada bulan Januari dan Februari didominasi oleh angin baratan. Munculnya beberapa pusat tekanan rendah dan siklon tropis di selatan Jawa pada bulan Februari 2013 mengakibatkan terjadinya perubahan arah angin yang sangat tegas. Arah angin pada level $850 \mathrm{mb}$ di Jawa pada awal hingga pertengahan Februari 2013 bertiup dari barat ke timur seperti ditunjukkan pada Gambar 1.

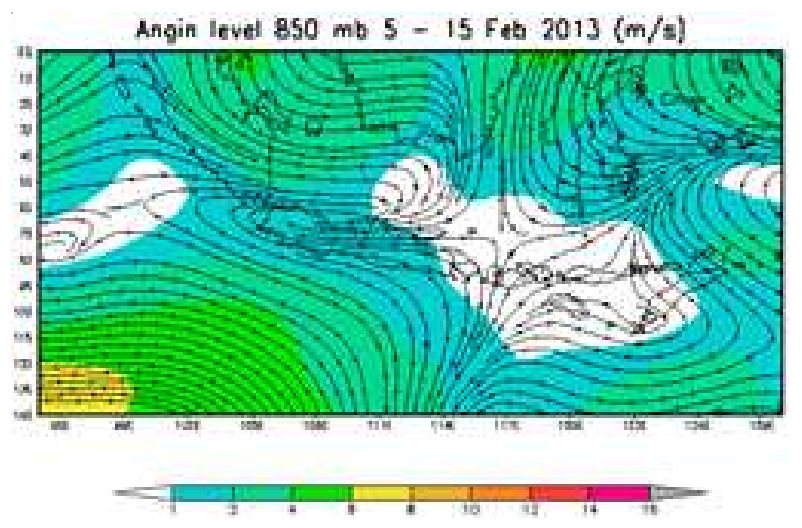

Gambar 1. Pola angin level $850 \mathrm{mb}$ pada tanggal 5-15 Februari 2013yang menunjukkan angin timuran di Jawa akibat pengaruh tekanan rendah di sebelah barat daya Sumatera. 
Pada pertengahan hingga akhir Februari 2013, angin kembali berubah menjadi angin baratan dengan kecepatan yang cukup tinggi seperti ditunjukkan pada Gambar 2.

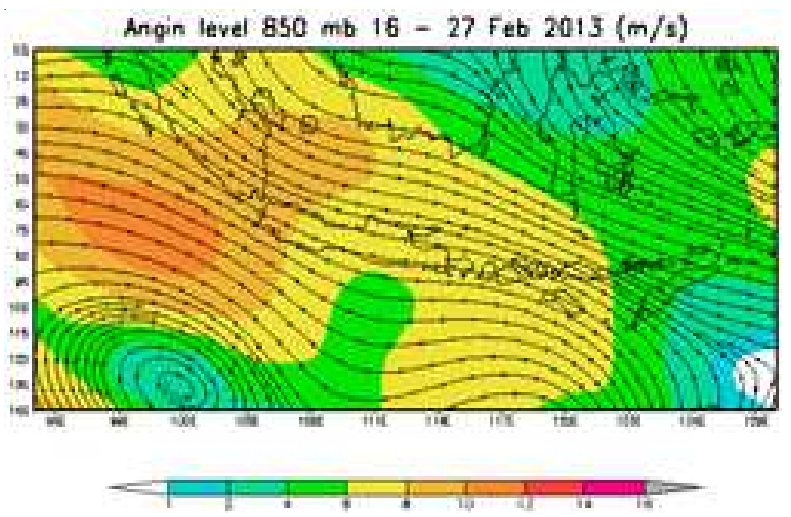

Gambar 2. Pola angin level $850 \mathrm{mb}$ pada tanggal 16-27 Februari 2013.

Berikut ini adalah perubahan harian arah dan kecepatan angin pada area $5.8^{\circ}-6.8^{\circ} \mathrm{LS}$ dan $106.3^{\circ}$ - 107.3 BT selama kegiatan TMC berlangsung. Kecepatan angin pada level ketinggian $850 \mathrm{mb}$ dari tanggal 26 Januari - 27 Februari 2013 bervariasi antara $1 \mathrm{~m} / \mathrm{s}$ sampai dengan $20 \mathrm{~m} / \mathrm{s}$ (lihat Gambar 3 ). Pada minggu pertama kegiatan TMC, kecepatan angin bervariasi antara 4-10 m/s. Pada saat ini terdapat dua sistem pusat tekanan rendah yang mempengaruhi pergerakan massa udara di Jawa bagian barat yaitu di Samudra Hindia sebelah barat Pulau Jawa dan di barat laut Australia.
Massa udara dari Laut Cina Selatan di utara bertemu dengan massa udara dari selatan membentuk daerah ITCZ memanjang mulai dari Lampung, Laut Jawa hingga Nusa Tenggara.

Masuk bulan Februari 2013, pusat tekanan rendah di barat laut Australia bergeser ke selatan sehingga pengaruhnya terhadap angin di Pulau Jawa semakin melemah. Di sisi lain muncul kembali pusat tekanan rendah di sebelah barat daya Sumatera. Kondisi ini mengakibatkan angin baratan di atas Pulau Jawa bagian barat kecepatannya semakin berkurang. Pusat tekanan rendah di barat daya Sumatera terus bertahan dan cenderung semakin menguat menyebabkan massa udara yang bergerak dari Laut Cina Selatan setelah melewati Laut Jawa berbelok menuju pusat tekanan rendah di Barat daya Sumatera. Tarikan pusat tekanan rendah di Barat daya Sumatera inilah yang menyebabkan perubahan arah angin di Jawa bagian Barat yang tadinya angin baratan berubah menjadi angin timuran. Angin timuran ini kecepatannya tidak terlalu besar yaitu 1-5 m/s. Pusat tekanan rendah di barat daya Sumatera semakin menguat menjadi Siklon Tropis Gino. Pada saat terjadi Siklon Tropis Gino kecepatan angin timuran di Jawa bagian Barat mencapai $5 \mathrm{~m} / \mathrm{s}$. Kecepatan komponen angin barat-timur dan komponen angin utara-selatan dari tanggal 26 Januari sampai dengan 27 Februari 2013 pada level $850 \mathrm{mb}$ disajikan pada Gambar 4.

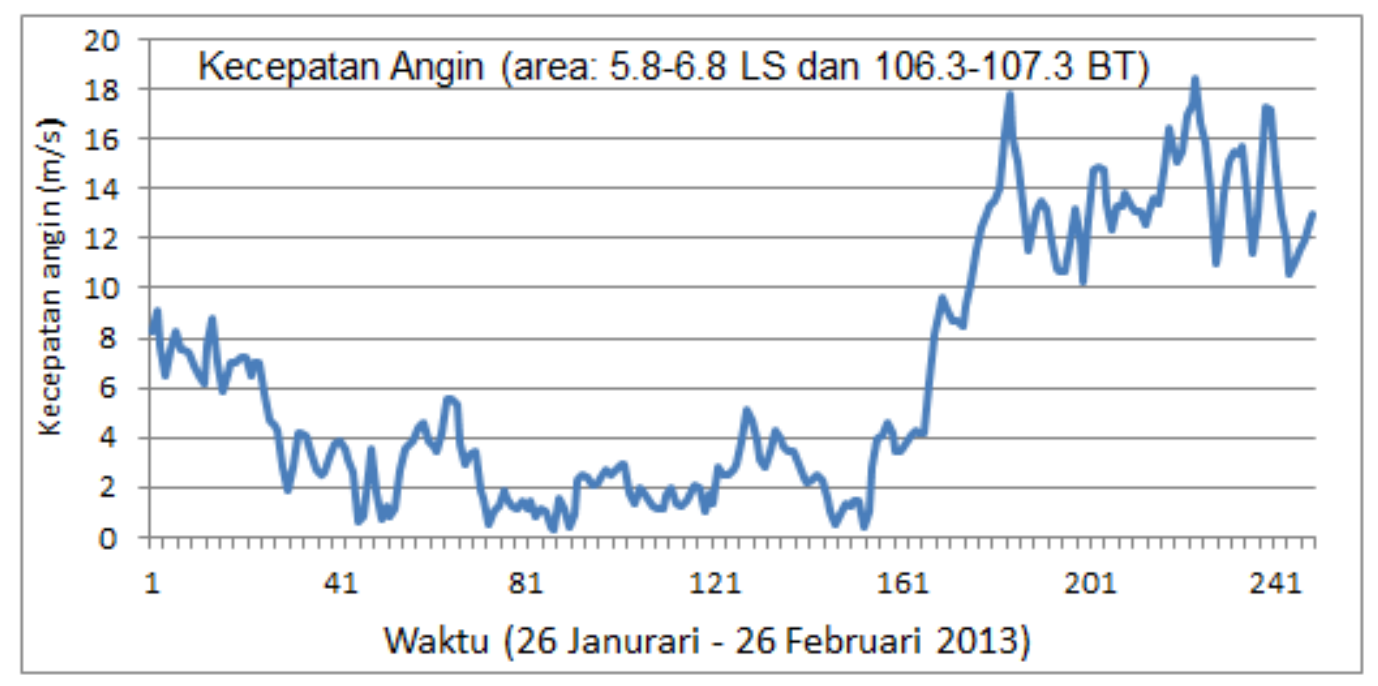

Gambar 3. Variasi kecepatan angin $(\mathrm{m} / \mathrm{s})$ tiga jam-an pada lapisan 850 $\mathrm{mb}$, rata rata area $5.8^{\circ}-6.8^{\circ} \mathrm{LS}$ dan $106.3^{\circ}-107.3^{\circ} \mathrm{BT}$ tanggal 26 Januari 27 Februari 2013.. (MERRA reanalisis) 


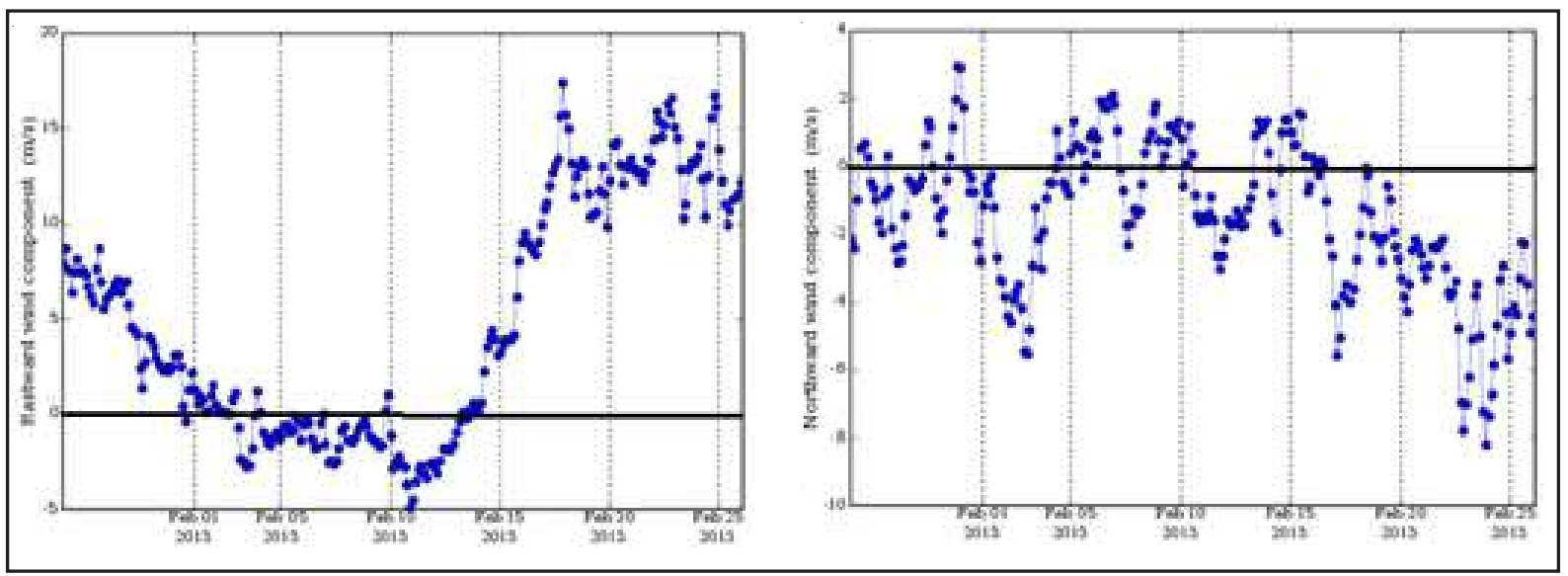

Gambar 4. Komponen angin timur-barat (kiri) dan utara-selatan (kanan) pada lapisan $850 \mathrm{mb}$, rata rata area $5.8^{\circ}-6.8^{\circ} \mathrm{LS}$ dan $106.3^{\circ}-107.3^{\circ} \mathrm{BT}$, tanggal 26 Januari -27 Februari 2013 (MERRA reanalisis).

Setelah Siklon Tropis Gino kekuatannya melemah dan menjauh ke arah selatan, pengaruhnya terhadap angin di Jawa bagian barat juga semakin kecil. Kecepatan angin timuran mulai berkurang dan berangsur angsur kembali lagi menjadi angin baratan yang mulai terlihat pada tanggal 15 Februari 2013. Angin baratan ini terus meningkat kecepatannya seiring dengan munculnya pusat tekanan rendah di utara Australia.

Pusat tekanan rendah di utara Australia semakin menguat menjadi depresi tropis dan bergerak ke arah barat daya. Akhirnya pada tanggal 24 Februari 2013 depresi tropis tersebut berubah menjadi Siklon Tropis Rusty dan posisinya sudah berada di sebelah barat laut Australia.

\subsection{Profil Angin Vertikal vs Waktu.}

Secara klimatologis, angin di Jawa bagian barat dominan bertiup dari barat hal ini terkait dengan pola monsoon Asia yang masih berlangsung pada bulan Januari dan Februari ini. Beberapa kali muncul pusat tekanan rendah dan siklon tropis di selatan Lampung dan sebelah barat Australia mengakibatkan terganggunya system angin monsoon di Jawa bagian barat.

Pada bagian sebelumnya telah disebutkan bahwa terjadi perubahan arah angin pada lapisan 850 $\mathrm{mb}$ dari angin baratan menjadi angin timuran pada awal hingga pertengahan Februari 2013. Pada bagian ini akan disampaikan profil vertikal perubahan arah angin tersebut.
Pada akhir Januari 2013 pola angin di Jawa bagian barat masih konsisten dengan system monsoon asia yaitu didominasi angin baratan. Pada tiga hari pertama kegiatan yaitu tanggal 26-29 Januari, angin baratan terlihat mulai dari lapisan bawah hingga ketinggian $500 \mathrm{mb}$. Pada lapisan di atasnya, kecepatan angin cenderung lebih rendah. Kemudian pada akhir Januari sampai awal Februari kecepatan angin baratan pada lapisan bawah sampai ketingian $500 \mathrm{mb}$ semakin lemah dan cenderung mulai mengalami pembelokan arah menjadi angin timuran dengan kecepatan relatif masih rendah.

Tanggal 3 Februari angin timuran mulai konsisten dengan kecepatan angin yang semakin tinggi. Angin timuran terdeteksi dari lapisan bawah sampai ketinggian $300 \mathrm{mb}$. Kondisi demikian bertahan hingga tanggal 13 Februari. Dalam kurun waktu tersebut, kecepatan angin timuran semakin ke atas semakin kencang. Selanjutnya pada tanggal 14 Februari mulai terjadi perubahan arah angin dari angin timuran kembali menjadi angin baratan. Namun demikian angin baratan ini hanya terdeteksi sampai ketinggian sekitar $400 \mathrm{mb}$. Pada lapisan di atas $400 \mathrm{mb}$ masih terjadi angin timuran.

Angin baratan ini kecepatannya terus menguat dan ketinggiannya mencapai lapisan $400 \mathrm{mb}$. Pada lapisan $850 \mathrm{mb}$ - $450 \mathrm{mb}$ terlihat kecepatan angin baratan sangat kuat. Hal ini ada kaitannya dengan Siklon Tropis di sebelah barat laut Australia. Massa udara tertarik ke arah pusat Siklon Tropis menimbulkan angin kencang di Jawa bagian barat yang berlangsung mulai tanggal 20 Februari sampai kegiatan TMC berakhir. Profil kecepatan angin vertikal di Jawa bagian barat dari tangal 26 Januari sampai dengan 27 Februari 2013 disajikan pada Gambar 5. 


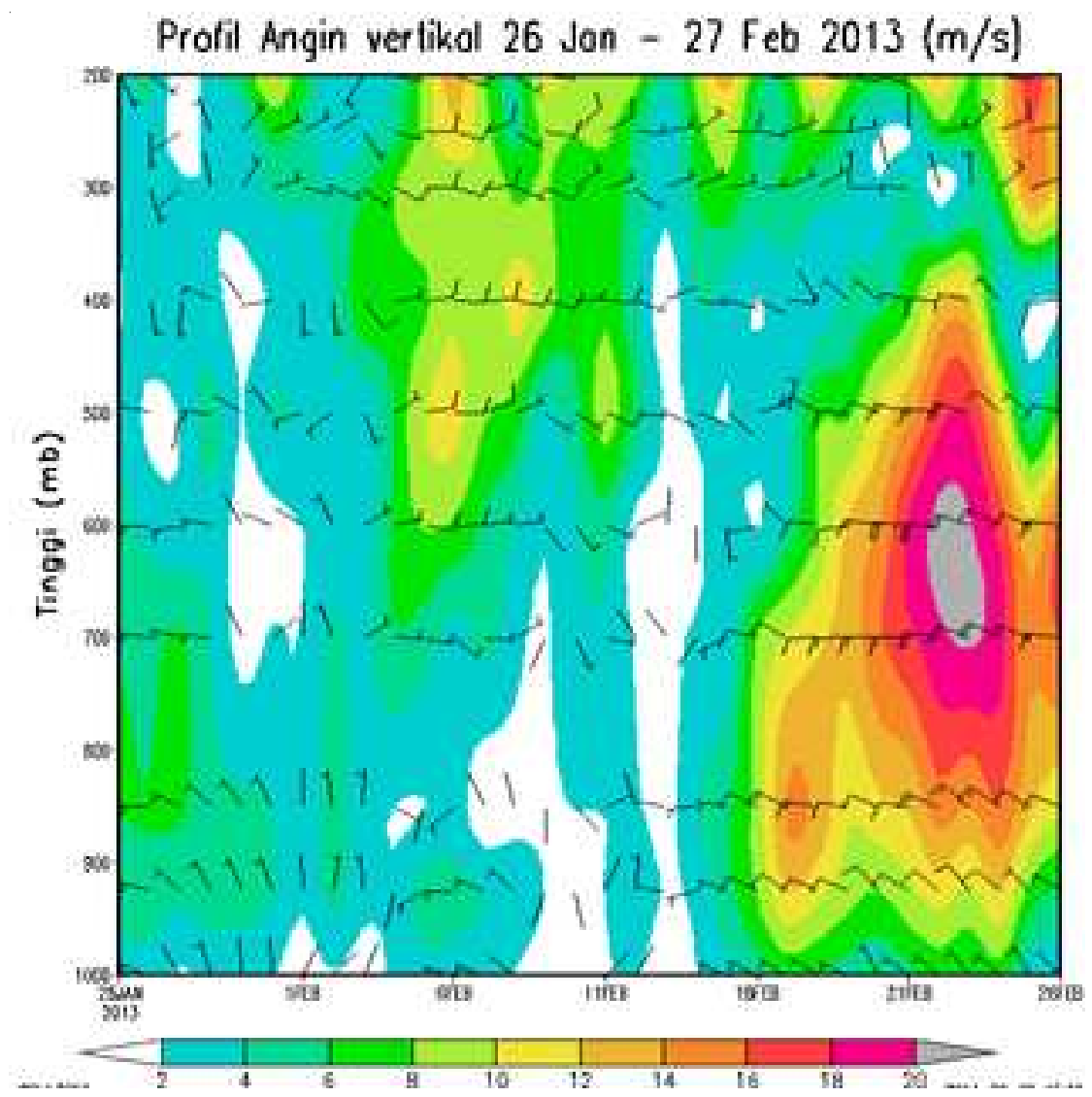

Gambar 5. Profil vertikal arah dan kecepatan angin di Jawa bagian barat tanggal 26 Januari - 27 Februari 2013. (NCEP reanalisis).

\section{KESIMPULAN}

Arah dan kecepatan angin di Jawa bagian barat selama kegiatan redistribusi hujan di wilayah Jakarta dan sekitarnya melalui penerapan TMC dapat disimpulkan sebagai berikut:

1. Daerah Jawa bagian barat merupakan daerah pertemuan massa udara dari selatan dengan masa udara dari utara membentuk daerah konvergensi angin.

2. Arah dan kecepatan angin masih dipengaruhi oleh system monsoon Asia - Australia serta keberadaan depresi tropis maupun siklon tropis di sebelah barat daya Sumatera dan di sebelah utara hingga barat laut Australia.

3. Terjadi pembalikan arah angin dari angin baratan menjadi angin timuran pada awal hinga pertengahan Februari 2013 terkait dengan adanya Siklon Tropis Gino di sebelah barat daya Sumatera.

4. Pada akhir kegiatan, terbentuk Siklon Tropis Rusty di barat laut Australia yang mengakibatkan angin kencang di Jawa bagian barat pada ketinggian 950 $\mathrm{mb}$ sampai dengan $450 \mathrm{mb}$.

\section{DAFTAR PUSTAKA}

Aldrian, E., 2000, Pola Hujan Rata-rata bulanan Wilayah Indonesia, Tinjauan Hasil Kontur Data Penakar dengan Resolusi ECHAM T42, Jurnal Sains \& Teknologi Modifikasi Cuaca, Vol. 1, No. 2, 2000:113-123 2002 : Spatial Pattern of ENSO Impact on Indoensia Rainfall, Jurnal Sains dan Teknologi Modifikasi Cuaca, Vol. 3, No. 1, p. 515.

Aldrian, E. and , R.D. Susanto, 2003, : Indentification of the Three Dominant Rainfall Regions within Indonesia and their Relationship to Sea Surface Temperature, International Journal of Climatology, 23, 1435-1452.

Hamada, J.I., 1995 : Climatological Studi on rainfall Variation In Indonesia. Master Thesis, Kyoto Univ.

Kane, R.P., 1997 : Relationship of El Nino-Southern Oscillation and Pacific Sea Surface Temperature with Rainfall in Various Region of the Globe, Mon, Wea. Rev., 125, 1792-1800. 
Mulyana. E., 2002 : Hubungan ENSO dengan Variasi Curah Hujan di Indonesia, Jurnal Sains dan Teknologi Modifikasi Cuaca, Vol. 3, No. 1, p. 14.

2002 : Pengaruh Dipole Mode terhadap Curah Hujan di Indonesia, Jurnal Sains dan Teknologi Modifikasi Cuaca, Vol. 3, No. 1, p. 39-43.

Ramage, C. S., 1968: Role of a tropical "maritime continent" in the atmospheric circulation. Mon. Wea. Rev., 96

Ropelewski, C.F. and M.S. Halpert, 1987, 1987 : Global and Regional Scale Precipitation Pattern Associated with the El Nino/Southern Oscillation, Mon, Wea. Rev., 115, 1606-1628.

Seto. T.H., 2002 : Pengamatan Osilasi Madden Julian dengan Radar atmoefer Equator (EAR) di Bukittinggi Sumatera Barat (Sebuah Studi Pendahuluan), Jurnal Sains dan Teknologi Modifikasi Cuaca, Vol. 3, No. 2, p. 121-124. 